\title{
Successful Treatment of Refractory Gastrointestinal Bleeding by Systemic (Oral) Ankaferd Blood Stopper in a Patient with Glanzmann Thrombasthenia
}

\author{
Sibel Kabukçu Hacıoğlu, Mehmet Hilmi Doğu, İsmail Sarı, Ali Keskin
}

Department of Hematology, Pamukkale University Faculty of Medicine, Denizli, Turkey

Background: Glanzmann Thrombasthenia (GT) is a genetic platelet dysfunction and a life threatening disease. Ankaferd Blood Stopper (ABS) is a topical hemostatic agent of herbal origin which has been recently made available for clinical use. Its hemostatic effect is independent from blood clotting factors and occurs as a result of the aggregation of focal red blood cells by an encapsulated protein web.

Case Report: In this paper, a patient with GT is presented in whom 3 months of gastrointestinal bleeding refractory to all medical therapies was controlled within a short time of using oral ABS.

Conclusion: The difference between this patient and other cases presented in the medical literature is the oral use of ABS. Thus, this patient may contribute to the medical community in showing the safety and efficacy of systemic (oral) ABS in patients with disorders of coagulation. However, there is a need for more patient experiences.

Keywords: Ankaferd Blood Stopper, disorders of hemostasis, Glanzmann thrombasthenia, oral systemic administration
Glanzmann Thrombasthenia (GT) is a genetic platelet dysfunction and a life threatening disease. Although it is a rare disease, it is the most common genetic platelet disorder. Symptoms and signs are mucosal and dermal petechia, recurring epistaxis and gastrointestinal (GI) bleeding and menorrhagia. Findings may be mild to life threatening in severity (1).

Ankaferd Blood Stopper (ABS) is a topical hemostatic agent of herbal origin which has recently become available for clinical use (2). It has been approved by the Turkish Republic Health Ministry for local use in bleeding due to superficial skin and dental disease. In the literature, there is a vast number of case reports regarding the application of ABS in gastrointestinal bleeding after surgical and dental procedures, both clinically and experimentally $(3,4)$.

In this case presentation, a patient with GT is reported in whom 3 months of gastrointestinal bleeding refractory to all medical therapies was controlled within a short time of using oral ABS.

\section{CASE PRESENTATION}

A 29 year-old female patient was diagnosed with GT at 13 years of age. She did not experience a significant bleeding episode requiring medical intervention except menorrhagia until she was 24 years-old, at which time she was admitted to our clinic. Her diagnosis was confirmed with a history of mucosal bleeding, the existence of GT in her sister, and prolonged collagen-ADP and collagen epinephrine assays with Platelet Function Analyzer (PFA-100; Dade Behring, Marbourg, Germany). While her platelet counts were normal, the PFA and bleeding time were prolonged and no response was seen to all agonists except ristocetin by light transmission aggregometry (Chrono-log Whole-Blood Lumi-Aggregometer 560-CA with AGGRO/LINK ${ }^{\circledR}$ 5.1, Chrono-log Corp, Haverton, PA, USA). Surgical intervention for a diagnosis of endometriosis was performed with apheresis platelet suspension support, with-

Address for Correspondence: Dr. Sibel Kabukçu Hacıoğlu, Department of Hematology, Pamukkale University Faculty of Medicine, Denizli, Turkey Phone: +90 5327317763 e-mail: skabukcu@gmail.com

Received: 12.10.2014 Accepted: 10.01.2015 • DOI: 10.5152/balkanmedj.2015.15734

Available at www.balkanmedicaljournal.org

Cite this article as:

Kabukçu Hacıoğlu S, Doğu MH, Sarı İ, Keskin A. Successful treatment of refractory gastrointestinal bleeding by systemic (oral) ankaferd blood stopper in a patient with Glanzmann thrombasthenia.

Balkan Med J 2015;32:218-20. 


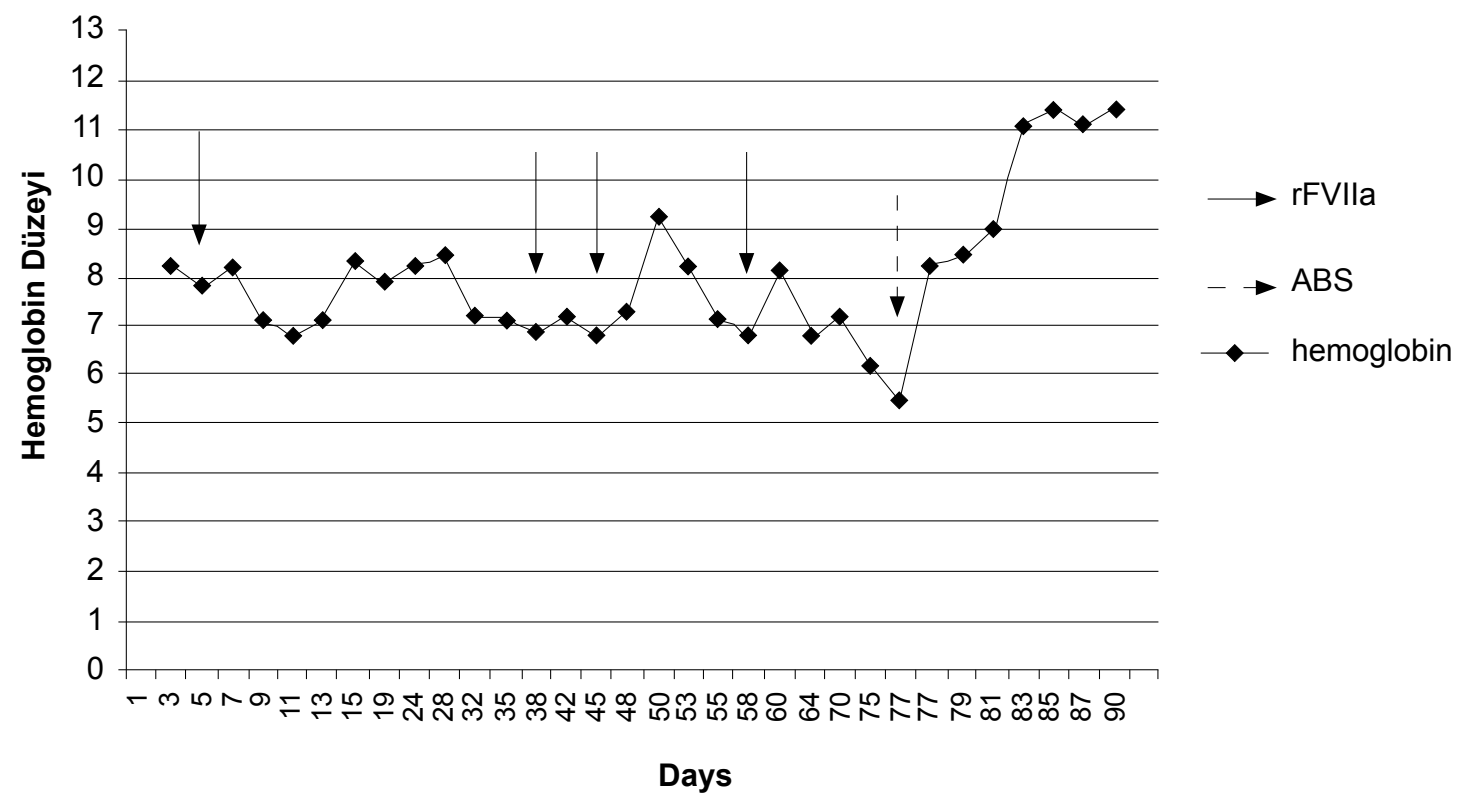

FIG. 1. Hemoglobin levels during gastrointestinal bleeding and effect of Ankaferd Blood Stopper

The bleeding in the patient can be seen to have been ameliorated from the first day of hospitalization and the Hb levels are shown for a 90 day period. Straight arrows indicate the days where rFVIla was administered, while dotted lines indicate the initiation of ABS. rFVIlla: recombinant factor VIla; ABS: Ankaferd Blood Stopper

out complications at that time. There was only one episode of menorrhagia 4 years ago which was unresponsive to antifibrinolytic and high dose progesterone treatment and apheresis platelet transfusions, and the menorrhagia was controlled with recombinant factor VIIa (rFVIIa). She was followed up for 4 years without any problem. Three months ago, she had taken non-steroidal anti-inflammatory drugs and was admitted at a different medical center due to dark stools. The GI system bleeding had continued in spite of all interventions, including apheresis platelet suspension, octostim, and rFVIIa, and then she was referred to our institution. Upon admission, her hemoglobin level was $7.1 \mathrm{~g} / \mathrm{dL}$, and platelet count was $320 \times 10^{9} / \mathrm{L}$. Oral feeding was stopped; a proton pump inhibitor was given with the addition of daily apheresis platelet support. The origin of bleeding was not detected with GI endoscopic intervention. As the bleeding continued, supportive therapies such as tranexamic acid, vitamin $\mathrm{K}$, and fresh frozen plasma were administered in addition to platelet and red blood cell replacements. Because the patient did not respond to any treatments, she was given rFVIIa on the $38^{\text {th }}, 45^{\text {th }}$, and $58^{\text {th }}$ days at a dose of $90 \mu \mathrm{g} / \mathrm{kg}, 3$ times with 2 hour intervals, but bleeding could not be stopped. She was given ABS by oral administration at a dose of $3 \times 4 \mathrm{~mL}$ because the origin of the bleeding had not been determined and owing to a life threatening reduction in hemoglobin levels in contrast with support of red blood cell transfusion. She gave informed consent before administration of the drug. The hemoglobin levels stabilized on the $3^{\text {rd }}$ day and the stool color began to return to normal on the $5^{\text {th }}$ day.
This treatment was continued for 10 days. The bleeding symptoms disappeared and hemoglobin levels returned to normal at the end of the $10^{\text {th }}$ day, and the patient began to be followed without treatment (Figure 1). The patient was administered a total of 70 units of apheresis platelets and 82 units of erythrocyte suspension during the 85 day process starting from the beginning of bleeding until the bleeding was controlled.

\section{DISCUSSION}

The bleeding episodes in GT are mostly mucosal bleeding, and the most frequent reasons for admittance to the hospital are gingival bleeding, epistaxis and serious menorrhagia (1). Unfortunately, treatment of patients with serious gastrointestinal bleeding as a life-threatening bleed is difficult. Bakdash et al. (5) could not control the bleeding in a 48-year-old female patient with endoscopic intervention, HLA-matched platelet transfusions and rFVIIa, and reported controlling the bleeding with partial gastrectomy after platelet transfusions and rFVIIa support. Bhat et al. (6) used rFVIIa in their patient with GT when the patient was 4-years-old for an upper gastrointestinal system bleed, and when the patient was 9-years-old for a lower GI system bleed; they reported improvement in bleeding in their study following their experience with rFVIIa in life-threatening bleeds.

Ankaferd Blood Stopper is a mixture of a number of herbs, and its effects on endothelial cells, blood cells, angiogenesis, 
cell proliferation, vascular dynamics and/or mediators were shown. Its hemostatic effect is independent from blood clotting factors and occurs as a result of the aggregation of red blood cells by an encapsulated protein web (2). It has been used in Turkey in many clinical cases of bleeding in which conventional measures were not sufficient for control of the episode.

The success of ABS in patients with a normal hemostatic system was mostly shown for gastrointestinal bleeds (3) and dental applications (4). All of these applications were local administrations, with a median ABS amount of between $1 \mathrm{~mL}$ and $20-30 \mathrm{~mL}$.

As the patient presented in this paper has a hemostasis defect, the medical literature on ABS applications in patients with a disorder of hemostasis was investigated, and more limited data were found. The activity of ABS was shown in 27 hemophilia A patients for the control of bleeding following tooth extraction (7) and in 4 patients with von Willebrand disease, chronic liver disease, and mitral valve replacement for the cessation of localized bleeding following dental procedures (8). Furthermore, the successful local application of ABS has been reported for massive hematuria in a hemodialysis patient complicated with disseminated intravascular coagulation (9), and upper gastrointestinal bleeding in a patient in whom a severe immune thrombocytopenia had developed (10).

In the first of several reports in the literature on its use in patients with GT is report of a 24-year-old patient in who uncontrollable tooth gum bleeding during periodontal treatment was controlled by the local use of ABS (11). In the others, the efficacy of ABS was shown in oral cavity bleeding in 2 patients with GT, and in another 12 patients with hemophilia A or with other factor deficiencies (12).

In conclusion, $\mathrm{ABS}$ might be effective in patients with GT who have refractory GI bleeding. Another difference of this patient in comparison with other cases presented in the medical literature is the oral use of ABS. In only a few recent studies have high doses of oral ABS been reported to be safe in healthy rats (13) and tandem oral, rectal, and nasal administrations in patients with Klatskin tumor (14). Although this patient may contribute to the medical community in showing the safety and efficacy of systemic (oral) ABS in patients with disorders of hemostasis, it is obvious that further experience on its use in patients and further clinical studies are needed.

\section{Ethics Committee Approval: N/A.}

Informed Consent: Written informed consent was obtained from the patient.

Peer-review: Externally peer-reviewed.

Author contributions: Concept - İ.S., S.K.H.; Design - S.K.H.; Supervision - A.K., İ.S.; Resource - S.K.H.; Data Collection \&/or Processing - M.H.D., S.K.H.; Analysis \&/or Interpretation - S.K.H.,
M.H.D.; Literature Search - S.K.H.; Writing - S.K.H.; Critical Reviews - S.K.H., İ.S., A.K.

Conflict of Interest: No conflict of interest was declared by the authors.

Financial Disclosure: The authors declared that this study has received no financial support.

\section{REFERENCES}

1. Franchini M, Favaloro EJ, Lippi G. Glanzmann thrombasthenia: an update. Clin Chim Acta 2010;41:1-6. [CrossRef]

2. Beyazit Y, Kurt M, Kekilli M, Goker H, Haznedaroglu IC. Evaluation of hemostatic effects of Ankaferd as an alternative medicine. Altern Med Rev 2010;15:329-36.

3. Beyazit Y, Kekilli M, Haznedaroglu IC, Kayacetin E, Basaranoglu M. Ankaferd hemostat in the management of gastrointestinal hemorrhages. World J Gastroenterol 2011;17:3962-70. [CrossRef]

4. Beyazit Y, Kart T, Kuscu A, Arslan A, Kurt M, Aktas B, et al. Successful management of bleeding after dental procedures with application of blood stopper: a single center prospective trial. $J$ Contemp Dent Pract 2011;12:379-84. [CrossRef]

5. Bakdash S, Lyons JM, Bastacky SI, Pezzone MA, McGee JB, Schoen $\mathrm{RE}$, et al. Management of persistent gastric bleeding in a patient with Glanzmann's thrombasthenia. Am J Hematol 2008;83:411-5. [CrossRef]

6. Bhat S, Yadav SP, Anjan M, Dinand V, Sachdeva A. Recombinant activated factor VII usage in life threatening hemorrhage: a pediatric experience. Indian J Pediatr 2011;78:961-8. [CrossRef]

7. Kazancığlu HO, Cakır O, Ak G, Zülfikar B. The Effectiveness of a New Hemostatic Agent (Ankaferd Blood Stopper) for the Control of Bleeding following Tooth Extraction in Hemophilia: A Controlled Clinical Trial. Turk J Haematol 2013;30:19-24. [CrossRef]

8. Baykul T, Alanoglu EG, Kocer G. Use of Ankaferd Blood Stopper as a hemostatic agent: a clinical experience. J Contemp Dent Pract 2010;11:88-94.

9. Solak Y, Gaipov A, Ozbek O, Hassan MA, Yeksan M. Massive haematuria successfully managed by intravesical Ankaferd in a haemodialysis patient complicated with disseminated intravascular coagulation. BMJ Case Rep 2012;2012.

10. Ozseker B, Shorbagi A, Efe C, Haznedaroglu IC, Bayraktar Y. Controlling of upper gastrointestinal bleeding associated with severe immune thrombocytopenia via topical adjunctive application of Ankaferd blood stopper. Blood Coagul Fibrinolysis 2012;23:464. [CrossRef]

11. Sonmez M, Baltacioğlu E, Sarac O, Erkut N. The use of Ankaferd blood stopper in a patient with Glanzmann's thrombasthenia with gingival bleeding. Blood Coagul Fibrinolysis 2010;21:382-83. [CrossRef]

12. Leblebisatan G, Bay A, Karakus SC, Kekilli M, Haznedaroglu IC. Topical Ankaferd hemostat application for the management of oral cavity bleedings in children with hemorrhagic diathesis. Blood Coagul Fibrinolysis 2012;23:494-97. [CrossRef]

13. Akbal E, Köklü S, Astarcı HM, Koçak E. Oral high-dose ankaferd administration effects on gastrointestinal system. Int J Med Sci 2013;10:451-6. [CrossRef]

14. Kurt M, Oztas E, Kuran S, Onal IK, Kekilli M, Haznedaroglu IC. Tandem oral, rectal, and nasal administrations of Ankaferd Blood Stopper to control profuse bleeding leading to hemodynamic instability. Am J Emerg Med 2009;27:631. [CrossRef] 